\title{
Screening of Tomato Genotypes for Various Yield and Quality Parameters under Regulated Deficit Irrigations in Northern Dry Zone of Karnataka
}

\author{
G. Prakash*, Muksh L. Chavan, R.C. Jagadeesha, J. Jayappa and K.S. Shankarappa
}

Kittur Rani Channamma College of Horticulture Arabhavi, Karnataka -591 218, India

*Corresponding author:

\section{Keywords}

Tomato stress, Deficit irrigation, Morphological traits, Yield, IW/CPE ratio

Article Info

Accepted:

18 January 2019

Available Online:

10 February 2019

\section{A B S T R A C T}

Tomato is one of the most popular and widely grown vegetables in the world which ranks next to potato. Although tomato is generally grown under irrigated conditions, its cultivation as a rainfed crop has gained importance particularly in semi-arid regions. It has been established that stress due to water deficit is a very important limiting factor at the initial phase of plant growth and establishment. Studies on physiological evaluation of tomato genotypes is limiting in the drought stress condition. Hence, the present investigation was carried out to screen the tomato genotypes for various Number of fruits / plant, Average fruit weight, Equatorial diameter $(\mathrm{mm})$, Polar diameter $(\mathrm{mm})$, Pericarp thickness, Number of locules/fruit, Yield/plant Yield/ hectare, Carotenoid content, TSS, Ascorbic acid content, Lycopene content and yield potential by adopting simple field screenings with regulated two levels of irrigation at two different stages of plant growth to know the effect of drought on tomato genotypes. The experiment was laid out in a factorial randomized block design with thirteen genotypes and two replications. Water stress was imposed two weeks after the transplanting to all the genotypes in two stress conditions viz the IW/CPE ratio of $0.40,1.20$ and farmers practice as control. Furrow irrigation was given when the pan evaporation reading reached $41.66 \mathrm{~mm}(1.20 \mathrm{IW} / \mathrm{CPE}$ ratio $)$ and 125 $\mathrm{mm}(0.40 \mathrm{IW} / \mathrm{CPE}$ ratio) using $\mathrm{V}$ notch. Under moisture stress condition of $1.2 \mathrm{IW} / \mathrm{CPE}$ ratio the genotype, Arka Meghali had significantly higher yield (1.65 kg plant ${ }^{-1}$ and $49.95 \mathrm{t}$ $\mathrm{ha}^{-1}$ ) and under the sever moisture stress of 0.4 IW/CPE ratio higher yield was noticed in the genotype EC 631962 (1.37 kg plant ${ }^{-1}$ and $\left.39.48 \mathrm{t} \mathrm{ha}^{-1}\right)$ and least yield was noticed in the susceptible genotype EC $608269\left(0.66 \mathrm{~kg} \mathrm{plant}^{-1}\right)$ at $0.4 \mathrm{IW} / \mathrm{CPE}$ ratio. Irrespective of the irrigation levels, EC 638519 had maximum number of fruits per plant. Genotypes EC 608362, EC 610652, EC 634394, EC 638519, EC 610661, EC 631962, Kashi Anupam and Pusa 120 performed better under drought conditions

\section{Introduction}

Drought is an important abiotic stress affecting the productivity of all crops, to date the progress achieved in improving drought resistance is very minimal. Among the specific reasons listed for slow progress are the multiplicity of drought patterns and the plant responses are foremost. Tomato is one of the most popular and widely grown 
vegetables in the world which ranks next to potato. Although tomato is generally grown under irrigated conditions, its cultivation as a rainfed crop has gained importance particularly in semi-arid regions. It has been established that drought stress is a very important limiting factor at the initial phase of plant growth and establishment. Drought affects both elongation and expansion growth. water deficit in the early stages of tomato showed a greater effect on reduction in plant height. There are several physiological, genetical and biochemical traits contributing to the drought tolerance nature of agricultural/ horticultural crops. Large number of tomato. Plants which tolerate moderate stress at low tissue water potential may do so by virtue of several dehydration tolerance mechanisms like maintenance of membrane integrity, osmotic adjustment and chloroplast integrity. Tomato genotypes have not been screened for drought tolerance for their cultivation. Hence, the present investigation was carried out to screen the tomato genotypes for various fruit yield and its quality related traits viz Number of fruits / plant, Average fruit weight, Equatorial diameter ( $\mathrm{mm})$, Polar diameter (mm), Pericarp thickness, Number of locules/fruit, Yield/plant Yield/ hectare, Carotenoid content, TSS, Ascorbic acid content, Lycopene content by adopting simple field technique of two levels of irrigation water to cumulative pan evaporation ratio (IW/CPE ratio) along with control.

\section{Materials and Methods}

The experiment was conducted at the Biotechnology and Crop Improvement unit of Kittur Rani Channamma College of Horticulture, Arabhavi, is situated in northern dry zone of Karnataka at $16^{\circ} 15^{\prime}$, north latitude, $75^{\circ} 45^{\prime}$ east longitude and at an altitude of 612.03 meters above mean sea level. The experiments were laid out in a factorial randomized block design with thirteen genotypes and two replications with the spacing of $60 \mathrm{~cm} \times 60 \mathrm{~cm}$ by following all the recommended production practices. Water stress was imposed after two weeks of transplanting to all the genotypes in both the IW/CPE ratio of $0.40,1.20$ and farmers practice as control. Furrow irrigation was given when the pan evaporation reading reached $41.66 \mathrm{~mm}$ (1.20 $\mathrm{IW} / \mathrm{CPE}$ ratio) and $125 \mathrm{~mm}$ (0.40 IW/CPE ratio) using $\mathrm{V}$ notch. The list of 13 tomato genotypes are 1)Arka Meghali, 2) EC 608362, 3)EC 610652, 4)EC $634394,5) \mathrm{EC} 638519,6) \mathrm{EC} 610661,7) \mathrm{EC}$ 631962, 8)EC 686550, 9)Kashi Anupam, 10)EC 686543, 11)EC 608269, 12) EC $686553,13)$ PUSA 120 were evaluated under this water deficit condition. The various traits viz Number of fruits / plant, Average fruit weight, Equatorial diameter $(\mathrm{mm})$, Polar diameter $(\mathrm{mm})$, Pericarp thickness, Number of locules/fruit, Yield/plant Yield/ hectare, Carotenoid content, TSS, Ascorbic acid content, Lycopene content and yield were recorded and subjected to analysis of variance.

\section{Results and Discussion}

The yield and yield attributing characters are basically governed by vegetative growth and its distribution. Yield is the function of many yield contributing character like number of fruits per plant, fruit weight, etc For number of fruits per plant, during experimental period, significant differences were found among irrigation levels, genotypes and their interaction (Table 1 and 2) and number of fruits per plant decreased as the frequency of irrigation decreased. Per cent reduction in number of fruits per plant was to extent of 22.82 per cent in studied genotypes Significantly higher number of fruits per plant was recorded in the genotype EC 638519 (93.82) at $0.4 \mathrm{IW} / \mathrm{CPE}$ ratio and followed by EC 610661 (89.01) and minimum was noticed in EC 608269 (15.48). Therefore, number of 
fruits per plant contributes much for plant yield both under control and stress. Thus, the genotypes which showed minimum per cent reduction in number of fruits per plant at 0.4 IW/CPE ratio over control such as EC 608362, EC 610652, EC 634394, EC 638519, EC 610661, EC 631962, Kashi Anupam and Pusa 120 are found to be drought tolerant. These results are in conformity with earlier findings of Chavan et al., (2011) in tomato, Yadav et al., (2003) in potato. Increase in the yield is a function of many yield contributing characters like fruit weight, it was decreased as the stress level increased.

Fruit weight decreased to the extent of 25.44 per cent, Irrespective of the irrigation levels, data indicated that among the genotypes, EC $631962(66.73 \mathrm{~g})$ recorded maximum fruit weight However, at $0.4 \mathrm{IW} / \mathrm{CPE}$ ratio higher fruit weight was recorded in the genotype EC 634394 followed by Pusa 120 and EC 631962. Further, these genotypes also showed minimum per cent reduction in the fruit weight. This investigation is in confirmity with the earlier study of Mukesh (2007) in tomato and Bhagavanthagoudra (2000) in cabbage.

Significant difference for yield per plant and yield per hectare were noticed among the irrigation levels, genotypes and their interaction during both experimentation (Table 3). Significant yield reduction was noticed as irrigation frequency reduced and reduction was to the extent of 21.92 and 22.95 per cent, respectively. Data on yield per plant of selected genotypes for experimental trail during second phase at $0.4 \mathrm{IW} / \mathrm{CPE}$ ratio showed significantly maximum yield in the genotype EC $631962(1.37 \mathrm{~kg} /$ plant $)$ followed by Arka meghali and EC 634394 (1.33 kg/plant), EC 608362 (1.28 kg/plant) and minimum was recorded in the genotype EC 608269 (0.66 kg/plant). These results are in conformity with findings of Sivakumar (2014c), Fruit yield showed significant differences among the genotypes and treatments.

Decrease in fruit yield was observed at 50 per cent FC level compared to 100 per cent FC. LE 114 recorded higher fruit yield $(1,372.64)$ followed by LE 118 (1,112.88), LE 57 (1,071.20) and LE 27 (948.96). The percentage yield reduction under drought over control has been suggested as the most important parameter for assessing drought tolerance than fruit yield. Renquist and Reid (2001) reported that, 38 per cent reduction of fruit yield due to the fall of the fruit size by 35 per cent appeared at the water deficit in the period of fruit formation.

Water stress decreased yield, flower number, fruit set percentage and dry matter production in all cultivars, but the reduction was greater in drought sensitive cultivars than in tolerant ones in tomato (Rahman et al., 1999a). Almeselmani et al., (2012) opined that, the yield and yield parameters were reduced significantly under drought condition in susceptible varieties than tolerant varieties in durum wheat. Water stress significantly decreased yield, yield components and dry matter production in both tolerant and sensitive tomato cultivars, but the reductions were more pronounced in the drought sensitive cultivar compared to the tolerant cultivar.

Ascorbic acid, TSS and lycopene content enhance the quality of fruits which are regulates the potential characters. Tomato is a rich source of ascorbic acid (Vit - C), which is a potent antioxidant protecting plants against oxidative damages imposed by environmental stress such as drought and ozone. The data indicated that, as the irrigation frequency decreased there was increase in ascorbic acid, lycopene and TSS content. It increased to the extent of 46.88, 50.39 and 28.74 per cent, respectively. 
Table.1 Number of fruits, average fruit weight (g), equatorial and polar fruit diameter in tomato genotypes as influenced by irrigation levels

\begin{tabular}{|c|c|c|c|c|c|c|c|c|c|c|c|c|c|c|c|c|c|}
\hline \multirow{3}{*}{$\begin{array}{l}\text { Sl. } \\
\text { No. }\end{array}$} & \multirow[t]{3}{*}{ Genotypes } & \multicolumn{4}{|c|}{ Number of fruits / plant } & \multicolumn{4}{|c|}{ Average fruit weight } & \multicolumn{4}{|c|}{ Equatorial diameter $(\mathrm{mm})$} & \multicolumn{4}{|c|}{ Polar diameter (mm) } \\
\hline & & \multicolumn{16}{|c|}{ IW/CPE ratio } \\
\hline & & Control & 1.2 & 0.4 & Mean & Control & 1.2 & 0.4 & Mean & Control & 1.2 & 0.4 & Mean & Control & 1.2 & 0.4 & Mean \\
\hline 1 & Arka Meghali & 29.41 & 26.89 & 25.58 & 27.29 & 65.35 & 61.36 & 52.03 & 59.58 & 39.47 & 32.55 & 30.74 & 34.26 & 38.91 & 36.67 & 28.34 & 34.64 \\
\hline 2 & EC 608362 & 27.32 & 26.07 & 23.25 & 25.55 & 70.54 & 57.50 & 55.38 & 61.14 & 34.27 & 31.52 & 27.21 & 31.00 & 38.32 & 36.01 & 30.37 & 34.90 \\
\hline 3 & EC 610652 & 29.46 & 26.04 & 25.31 & 26.93 & 56.09 & 55.50 & 48.38 & 53.32 & 35.95 & 32.90 & 27.44 & 32.09 & 40.14 & 34.32 & 29.16 & 34.54 \\
\hline 4 & EC 634394 & 27.36 & 25.10 & 22.14 & 24.86 & 67.95 & 60.75 & 60.40 & 63.03 & 41.51 & 35.23 & 31.63 & 36.12 & 42.04 & 37.53 & 32.81 & 37.46 \\
\hline 5 & EC 638519 & 128.27 & 113.63 & 93.82 & 111.91 & 13.06 & 12.86 & 13.58 & 13.17 & 12.56 & 11.20 & 9.20 & 10.99 & 14.87 & 12.06 & 9.58 & 12.17 \\
\hline 6 & EC 610661 & 108.03 & 96.57 & 89.01 & 97.87 & 14.68 & 13.61 & 13.62 & 13.97 & 11.86 & 9.92 & 8.77 & 10.18 & 13.82 & 11.44 & 9.42 & 11.56 \\
\hline 7 & EC 631962 & 24.71 & 25.54 & 23.75 & 24.67 & 79.28 & 64.84 & 56.08 & 66.73 & 38.60 & 32.00 & 27.13 & 32.58 & 44.93 & 34.43 & 28.45 & 35.93 \\
\hline 8 & EC 686550 & 26.74 & 21.63 & 16.68 & 21.68 & 67.24 & 59.51 & 38.32 & 55.02 & 33.84 & 28.73 & 21.52 & 28.03 & 44.70 & 31.37 & 24.64 & 33.57 \\
\hline 9 & Kashi Anupam & 25.95 & 26.28 & 24.69 & 25.64 & 64.04 & 53.07 & 50.44 & 55.85 & 42.01 & 33.69 & 27.17 & 34.29 & 36.26 & 32.00 & 28.91 & 32.39 \\
\hline 10 & EC 686543 & 27.05 & 20.02 & 17.11 & 21.39 & 62.38 & 54.37 & 39.10 & 51.95 & 28.48 & 26.27 & 21.48 & 25.41 & 37.35 & 27.23 & 21.38 & 28.65 \\
\hline 11 & EC 608269 & 26.92 & 19.83 & 15.48 & 20.75 & 62.26 & 61.59 & 34.75 & 52.87 & 33.56 & 24.77 & 20.95 & 26.42 & 35.19 & 24.22 & 23.26 & 27.56 \\
\hline 12 & EC 686553 & 27.50 & 21.53 & 16.48 & 21.84 & 59.55 & 55.81 & 33.83 & 49.73 & 32.74 & 24.52 & 21.39 & 26.22 & 36.21 & 25.79 & 22.46 & 28.15 \\
\hline 13 & PUSA 120 & 29.16 & 25.47 & 21.80 & 25.48 & 60.63 & 54.50 & 58.16 & 57.77 & 40.52 & 35.12 & 28.14 & 34.60 & 35.37 & 31.74 & 29.26 & 32.12 \\
\hline & Mean & 41.37 & 36.51 & 31.93 & 36.60 & 57.16 & 51.17 & 42.62 & 50.32 & 32.72 & 27.57 & 23.29 & 27.86 & 35.24 & 28.83 & 24.46 & 29.51 \\
\hline \multirow{3}{*}{\multicolumn{2}{|c|}{ Range }} & 128.27 & 113.63 & 93.82 & 111.91 & 79.3 & 64.84 & 60.40 & 66.73 & 42.01 & 35.23 & 31.63 & 36.12 & 44.9 & 37.53 & 32.81 & 37.46 \\
\hline & & 24.71 & 19.83 & 15.48 & 20.75 & 13.06 & 12.86 & 13.58 & 13.17 & 11.86 & 9.92 & 8.77 & 10.18 & 13.82 & 11.44 & 9.42 & 11.56 \\
\hline & & \multicolumn{2}{|c|}{ S.Em \pm} & \multicolumn{2}{|c|}{ CD@ 0} & \multicolumn{2}{|c|}{ S.Em \pm} & \multicolumn{2}{|c|}{ CD@ 5\% } & \multicolumn{2}{|c|}{ S.Em \pm} & \multicolumn{2}{|c|}{ CD@ 5\% } & \multicolumn{2}{|c|}{ S.Em \pm} & \multicolumn{2}{|c|}{ CD@ 5\% } \\
\hline \multirow{3}{*}{\multicolumn{2}{|c|}{$\begin{array}{l}\text { Genotypes (G) } \\
\text { Irrigation (I) } \\
\text { G X I }\end{array}$}} & \multirow{3}{*}{\multicolumn{2}{|c|}{$\begin{array}{l}0.87 \\
0.42 \\
1.51\end{array}$}} & \multicolumn{2}{|c|}{2.46} & \multicolumn{2}{|c|}{$\begin{array}{l}1.61 \\
0.77\end{array}$} & \multicolumn{2}{|c|}{4.53} & \multicolumn{2}{|c|}{0.29} & \multirow{2}{*}{\multicolumn{2}{|c|}{$\begin{array}{l}0.81 \\
039\end{array}$}} & \multicolumn{2}{|c|}{0.54} & \multicolumn{2}{|c|}{1.53} \\
\hline & & & & \multirow{2}{*}{\multicolumn{2}{|c|}{$\begin{array}{l}1.18 \\
4.25\end{array}$}} & 0.7 & & & & \multicolumn{2}{|c|}{0.14} & 0. & & \multicolumn{2}{|c|}{0.26} & \multicolumn{2}{|c|}{0.73} \\
\hline & & & & & & 2.7 & & & 85 & 0.5 & & 1. & 40 & 0.9 & & & 65 \\
\hline
\end{tabular}


Table.2 Pericarp thickness $(\mathrm{mm})$ and number of locules per fruit in tomato genotypes as influenced by irrigation levels

\begin{tabular}{|c|c|c|c|c|c|c|c|c|c|}
\hline \multirow{3}{*}{$\begin{array}{c}\text { Sl. } \\
\text { No. }\end{array}$} & \multirow[t]{3}{*}{ Genotypes } & \multicolumn{4}{|c|}{ Pericarp thickness } & \multicolumn{4}{|c|}{ Number of locules/fruit } \\
\hline & & \multicolumn{8}{|c|}{ IW/CPE ratio } \\
\hline & & Control & 1.2 & 0.4 & Mean & Control & 1.2 & 0.4 & Mean \\
\hline 1 & Arka Meghali & 4.14 & 3.18 & 2.57 & 3.30 & 3.79 & 4.36 & 5.10 & 4.42 \\
\hline 2 & EC 608362 & 4.03 & 3.06 & 2.39 & 3.16 & 4.15 & 4.30 & 3.78 & 4.08 \\
\hline 3 & EC 610652 & 3.69 & 3.34 & 2.40 & 3.14 & 3.77 & 3.89 & 3.59 & 3.75 \\
\hline 4 & EC 634394 & 3.75 & 3.10 & 2.58 & 3.14 & 3.55 & 3.69 & 3.37 & 3.54 \\
\hline 5 & EC 638519 & 1.46 & 1.20 & 0.98 & 1.22 & 3.31 & 3.14 & 2.72 & 3.06 \\
\hline 6 & EC 610661 & 1.41 & 1.17 & 0.93 & 1.17 & 3.12 & 3.07 & 3.33 & 3.17 \\
\hline 7 & EC 631962 & 4.30 & 2.88 & 2.35 & 3.18 & 4.08 & 4.00 & 4.25 & 4.11 \\
\hline 8 & EC 686550 & 2.85 & 2.57 & 1.59 & 2.34 & 3.44 & 2.67 & 3.04 & 3.05 \\
\hline 9 & Kashi Anupam & 3.54 & 3.02 & 1.83 & 2.79 & 4.28 & 3.94 & 3.93 & 4.05 \\
\hline 10 & EC 686543 & 3.51 & 2.28 & 1.21 & 2.33 & 3.87 & 3.07 & 2.75 & 3.23 \\
\hline 11 & EC 608269 & 3.46 & 2.17 & 1.23 & 2.29 & 3.86 & 2.70 & 2.83 & 3.13 \\
\hline 12 & EC 686553 & 3.68 & 2.49 & 1.56 & 2.58 & 3.82 & 2.88 & 3.00 & 3.23 \\
\hline 13 & PUSA 120 & 3.59 & 2.75 & 2.54 & 2.96 & 4.37 & 3.84 & 3.95 & 4.05 \\
\hline \multicolumn{2}{|c|}{ Mean } & 3.34 & 2.55 & 1.86 & 2.58 & 3.80 & 3.51 & 3.51 & 3.61 \\
\hline \multirow{3}{*}{\multicolumn{2}{|c|}{ Range }} & 4.30 & 3.34 & 2.58 & 3.30 & 4.4 & 4.36 & 5.10 & 4.42 \\
\hline & & 1.41 & 1.17 & 0.93 & 1.17 & 3.12 & 2.67 & 2.72 & 3.05 \\
\hline & & \multicolumn{2}{|c|}{ S.Em \pm} & \multicolumn{2}{|c|}{ CD@5\% } & \multicolumn{2}{|c|}{ S.Em \pm} & \multicolumn{2}{|c|}{ CD@ $@ 5 \%$} \\
\hline \multirow{3}{*}{\multicolumn{2}{|c|}{$\begin{array}{l}\text { Genotypes (G) } \\
\text { Irrigation (I) } \\
\text { G X I }\end{array}$}} & \multirow{3}{*}{\multicolumn{2}{|c|}{$\begin{array}{l}0.089 \\
0.042 \\
0.152\end{array}$}} & \multirow{3}{*}{\multicolumn{2}{|c|}{$\begin{array}{l}0.248 \\
0.119 \\
0.429\end{array}$}} & \multirow{3}{*}{\multicolumn{2}{|c|}{$\begin{array}{l}0.08 \\
0.04 \\
0.13\end{array}$}} & \multicolumn{2}{|c|}{0.21} \\
\hline & & & & & & & & & \\
\hline & & & & & & & & & \\
\hline
\end{tabular}


Table.4 Yield per plant (kg/plant) and yield per hectare (t/ha) in tomato genotypes as influenced by irrigation levels

\begin{tabular}{|c|c|c|c|c|c|c|c|c|c|}
\hline \multirow[t]{3}{*}{ Sl. No. } & \multirow[t]{3}{*}{ Genotypes } & \multicolumn{4}{|c|}{ Yield/plant } & \multicolumn{4}{|c|}{ Yield/ hectare } \\
\hline & & \multicolumn{8}{|c|}{ IW/CPE ratio } \\
\hline & & Control & 1.2 & 0.4 & Mean & Control & 1.2 & 0.4 & Mean \\
\hline 1 & Arka Meghali & 1.89 & 1.65 & 1.33 & 1.62 & 58.83 & 49.95 & 38.14 & 48.97 \\
\hline 3 & EC 610652 & 1.65 & 1.44 & 1.22 & 1.44 & 49.98 & 42.19 & 34.19 & 42.12 \\
\hline 4 & EC 634394 & 1.79 & 1.52 & 1.33 & 1.55 & 55.10 & 45.25 & 38.33 & 46.22 \\
\hline 5 & EC 638519 & 1.67 & 1.46 & 1.27 & 1.47 & 50.83 & 42.94 & 36.03 & 43.27 \\
\hline 7 & EC 631962 & 1.95 & 1.62 & 1.37 & 1.65 & 61.29 & 48.73 & 39.48 & 49.83 \\
\hline 8 & EC 686550 & 1.79 & 1.24 & 0.95 & 1.33 & 55.25 & 34.72 & 24.07 & 38.01 \\
\hline 9 & Kashi Anupam & 1.66 & 1.39 & 1.24 & 1.43 & 50.48 & 40.55 & 34.98 & 42.01 \\
\hline 10 & EC 686543 & 1.69 & 1.21 & 0.82 & 1.24 & 51.33 & 33.74 & 19.25 & 34.77 \\
\hline 11 & EC 608269 & 1.62 & 1.22 & 0.66 & 1.17 & 48.75 & 33.99 & 13.41 & 32.05 \\
\hline 12 & EC 686553 & 1.64 & 1.20 & 0.70 & 1.18 & 49.49 & 33.32 & 14.70 & 32.50 \\
\hline \multirow{2}{*}{\multicolumn{2}{|c|}{ Range }} & 1.59 & 1.20 & 0.66 & 1.17 & 47.61 & 33.32 & 13.41 & 32.05 \\
\hline & & \multicolumn{2}{|c|}{ S.Em \pm} & \multicolumn{2}{|c|}{ CD@ $@$ 5\% } & \multicolumn{2}{|c|}{ S.Em \pm} & \multicolumn{2}{|c|}{ CD@ 0 \% } \\
\hline \multirow{3}{*}{\multicolumn{2}{|c|}{$\begin{array}{l}\text { Genotypes (G) } \\
\text { Irrigation (I) } \\
\text { G X I }\end{array}$}} & \multirow{3}{*}{\multicolumn{2}{|c|}{$\begin{array}{l}0.04 \\
0.02 \\
0.06\end{array}$}} & \multirow{3}{*}{\multicolumn{2}{|c|}{$\begin{array}{c}0.1 \\
0.05 \\
0.17\end{array}$}} & & \multicolumn{2}{|c|}{3.64} \\
\hline & & & & & & \multicolumn{2}{|c|}{0.62} & \multicolumn{2}{|c|}{1.75} \\
\hline & & & & & & & & \multicolumn{2}{|c|}{6.30} \\
\hline
\end{tabular}


Among the genotypes at $0.4 \mathrm{IW} / \mathrm{CPE}$ ratio higher ascorbic acid, lycopene and TSS content were recorded in Pusa 120, EC 638519 and EC 638519 and whereas, EC 686553, EC 608269 and EC 686550 recorded minimum, respectively. Increasing the ascorbic acid content of leaves might be the effective strategy to protect the thylakoid membrane from oxidative damages in water stressed leaves and resulting in enhanced net photosynthesis and tolerance to drought as evidenced by Tambussi et al., (2000) in wheat. The results of Amor and Amor (2007) showed that, when irrigation was reduced by 50 per cent increased the $\mathrm{pH}$ by 13.2 per cent and TSS by 18.9 per cent and reduced acidity by 30 per cent in tomato fruits compared to full irrigation. The fruit quality improvement was observed under water deficit condition in tomato as a result of the synthesis of ascorbic acid, citric acid and malic acid (Nahar et al., 2011). Martino et al., (2006) also reported on tomato plants adaptation to environmental stress and reported that lycopene content in tomato fruits increased to 32 per cent under osmotic stress. Similarly Bang et al., (2004) studied the irrigation impact on lycopene on watermelon and reported that fruit lycopene content increased with maturity ( 7 and 22 days after ripening) at all the irrigation levels.

The genotypes EC 610652, EC 634394, EC 638519, EC 610661, EC 631962, and Pusa 120 were performed better under stress condition for the all the quality parameters and were found to be drought tolerant compared to local check Arka Meghali. These genotypes shall be source materials for improvement of varieties for water deficit condition.

\section{References}

Almeselmani, M., Saud, A. A. R., Hareri, F., Al-Nasan, M., Ammar, M. A., Kanbar, O. Z., and Al-Naseef, H., 2012,
Physiological traits associated with drought tolerance of Syrian durum wheat varieties under rainfed condition. Indian J. Plant Physiol., 17 (2): 166-169.

Amor, M. A. D. and Amor, F. M. D., 2007, Response of tomato plants to deficit irrigation under surface or subsurface drip irrigation. J. Appl. Hort., 9 (2): 97-100.

Bang, H., Sleskov, D. I., Bendra, D. A. and Crosby. K., 2004, Effect of irrigation impact on lycopene, soluble solids, firmness and yield of diploid and triploid watermelon in their distinct environment. J. Hort. Sci. Biotech., 79 (6): 885-890.

Bhagavanthagoudra, K. H. 2000, Studies on water and nutrient management in cabbage (Brassica oleracea var. capitata L.) cv. Pride of India. Ph. D. Thesis, Univ. of Agric. Sci., Dharwa.

Chavan, M. L., Janagoudar, B. S. and Mastiholi, A. B., 2010, Variability in biophysical parameters and pollen viability in response to stress in tomato genotypes. Indian J. Hort., 67: 232-237.

Martino, A., Raimondi, G., Merola, G., De Pascale, S., Maggio. A. and Fagnano, M., 2006, Can moderate osmotic stress reduce ozone injuries in tomato. In: Wieser, G. and M. Tausz. (Eds.). Critical levels of ozone: Further applying and developing the fluxbased concept. Austria. pp. 279-282. Mukesh L. Chavan (2007). Drought tolerance studies in tomato. Thesis, university of agricultural Sciences, Dharwad.

Rahman, S. M. L., Nawata, E. and Sakuratani, T., 1999, Effect of water stress on growth, yield and ecophysiological responses of four tomato (Lycopersicon esculentum mill.) 
cultivars. J. Jpn. Soc. Hort. Sci., 68: 499-504.

Renquist, A. R. and Reid, J. B., 2001, Processing tomato fruit quality: Influence of soil water deficits at anthesis and ripening. Aust. J. Agric. Res., 52: 793-799.

Sivakumar, R., D. Durga Devi., C. N. Chandrasekar., R. Santhi, and R. M. Vijayakumar (2014). Impact of drought on gas exchange and physiological parameters and yield in contrasting genotypes of tomato
(Solanum lycopersicum). Indian J. Plant Physiol. 19: 1-7.

Tambussi, E. A., Bartoli, C. G., Beltrano, J., Guiamet, J. J. and Araus, J. L., 2000, Oxidative damage to thylakoid proteins in water-stressed leaves of wheat (Triticum aestivum). Physiol. Plant., 108: 398-404.

Yadav, A. C., Singh, A., Brar, J. and Lal, S., 2003, Effect of irrigation and plant spacing on growth, yield and water use efficiency of potato cv. Kufri Sutlej. Haryana J. Hort. Sci., 32: 138140.

\section{How to cite this article:}

Prakash, G., Muksh L. Chavan, R.C. Jagadeesha, J. Jayappa and Shankarappa, K.S. 2019. Screening of Tomato Genotypes for Various Yield and Quality Parameters under Regulated Deficit Irrigations in Northern Dry Zone of Karnataka. Int.J.Curr.Microbiol.App.Sci. 8(02): 2275-2283. doi: https://doi.org/10.20546/ijcmas.2019.802.265 